\title{
SYNTHETIC EUROCURRENCY INTEREST RATE FUTURES CONTRACTS : THEORY AND EVIDENCE
}

\author{
Annie Koh \\ Richard Levich \\ Working Paper No. 3055 \\ NATIONAL BUREAU OF ECONOMIC RESEARCH \\ 1050 Massachusetts Avenue \\ Cambridge, MA 02138 \\ August 1989
}

\begin{abstract}
Comments from Robert Cumby, Stephen Figlewski, and Marti Subrahmanyam are gratefully acknowledged. Additional comments from Warren Bailey, Karen Lewis, Anthony Saunders, participants in the French Finance Association meetings (Paris), June 28-30, 1989, and participants in the Tokyo Conference on International Financial Markets, July 17-18, 1989 are also appreciated. We thank Interactive Data Corporation for allowing us access to their data resources. The authors acknowledged responsibility for any errors that remain. This paper is part of NBER's research program in International Studies. Any opinions expressed are those of the authors not those of the National Bureau of Economic Research.
\end{abstract}


NBER Working Paper \#3055

August 1989

SYNTHETIC EUROCURRENCY INTEREST RATE FUTURES CONTRACTS: THEORY AND EVIDENCE

\section{ABSTRACT}

In this paper, we develop a theoretical (arbitrage) pricing model for a Eurocurrency interest rate furres contract and measure its hedging effectiveness. This synthetic Eurocurrency interest rate funures contract is obtained by combining exisiting Eurodollar interest rate futures contracts with near term and far term currency furures contracts based on the covered interest rate parity relationship. In theory, the cash flows of the synthetic contract perfectly replicate the cash flows of a Eurocurrency interest rate futures contract. Our empirical results show that the synthetic contracts are relatively efficient in hedging non-dollar borrowing rates. These results have implications for the practice of hedging non-dollar interest rate risk and for the development of actual Eurocurrency interest rate futures markets.

Annie Koh

Department of Banking and Finance Faculty of Business Administration National University of Singapore 10 Kent Ridge Crescent

0511 Singapore
Richard Levich

New York University

Stern School of Business

100 Trinity Place

New York, NY 10006 
1. Introduction

Over the last several decades, the process of financial innovation has been building and gaining momentum. Two important trends stand out. ${ }^{1}$ The first is a proliferation of new products, many of which make possible funding strategies or investment strategies that circumscribe risks in ways that heretofore were not possible. A second trend is the decline in the importance of U.S. securities markets as a fraction of world market capitalization, and the decline in the role of the dollar as a numeraire in international financial markets.

An example of the first trend is the Eurodollar futures contract traded on the Chicago Mercantile Exchange. This contract began trading on December 9, 1981 and by 1984, its trading volume and open interest surpassed that of all other short-term interest rate hedging instruments. Today, the volume of trading in Eurodollar futures contracts typically surpasses 100,000 contracts daily ( $\$ 100$ billion of notional value) and recent research by Koh (1988) concludes that the Eurodollar futures contract is the most effective instrument for hedging interest rate risk in a variety of dollar-denominated securities.

To illustrate the second trend, as of December 1987 , only $60 \%$ of the market for short-term Eurocurrency deposits were dollar-denominated, and over the January-June

\footnotetext{
1 An extensive discussion of the major innovations in international financial markets, their causes and
} implications is presented in Levich (1988). 
1988 period only $40 \%$ of the new issues of Eurobonds were dollar-denominated. ${ }^{2}$ Despite this second trend, markets for hedging interest rate risk for non-dollar denominated assets have been slow to develop.

The purpose of this paper is to show that, despite the absence of specific instruments for hedging non-dollar interest rate risk, effective ways for managing this risk have existed for some time. First, we show that as a theoretical matter a synthetic nondollar interest rate futures contract can be created using available futures contracts -specifically, by using Eurodollar interest rate futures in conjunction with currency futures contracts. Second, we offer empirical evidence that these synthetic, non-dollar contracts have become increasingly effective at hedging non-dollar interest rate risks.

Our exposition of the synthetic interest rate futures contract should be familiar to those acquainted with the principles of covered interest arbitrage. In years past, the interest rate parity condition, $F=S(1+r) /\left(1+r^{*}\right)$, which links the forward exchange rate $(F$, in $\$$ per foreign currency unit) to the spot exchange rate (S) and the yield on domestic currency funds $(1+r)$ and foreign currency funds $\left(1+r^{*}\right)$, has been invoked as an equilibrium condition required to eliminate risk-free arbitrage profits. ${ }^{3}$

More recently, however, the forward exchange market has been interpreted as a vehicle that transforms the currency dimension of a security while leaving the other characteristics of the security unchanged ${ }^{4}$ For example, a synthetic non-dollar commercial paper security could be created by combining U.S. dollar commercial paper with a spot and

2 Both the Eurocurrency deposit market and the Eurobond market began in the 1960 s as wholely dollardenominaied markets. From the mid-1970s through the mid-1980s, roughly $70-80 \%$ of both markets were dollar-denominated. Data are from World Financial Markets August 17,1988.

3 For an extended discussion of the theory and empirical evidence on covered interest arbitrage, see Frenkel and Levich (1988),

4 This principle of currency transformation of assets or liabilities using forward contracts is well known from the literaure on foreign exchange risk management. For more details on the role of forward contracts in financial innovation, see Levich (1988). 
forward exchange contract. Similarly, the cash flows of a long-term, Deutsche mark (DM) denominated bond may be replicated by a dollar-denominated bond in conjunction with a collection of forward contracts, that is, a currency swap. Such combinations of forward exchange contracts with existing securities would clearly be useful to overcome the lack of existence of a particular market or to overcome costly regulations and controls that may exist.

In section 2, we draw on this principle and show how forward exchange contracts can be used to transform the currency of denomination of existing Eurodollar interest rate futures contracts. Empirical evidence on the hedging effectiveness of the synthetic contracts, and comparisons with an actual British pound sterling interest rate futures contract are presented in section 3 . Conclusions and policy implications are offered in the final section.

2. Arbitrage Pricing of Synthetic Eurocurrency Interest Rate Futures

In this section, we will demonstrate that a Eurocurrency interest rate futures contract for the interval $\left[t_{1}, t_{2}\right]$ can be replicated by selling (buying) a Eurodollar interest rate futures contract for delivery on $t_{1}$ combined with the purchase (sale) of a foreign currency futures contract for delivery on $t_{1}$ and the sale (purchase) of a foreign currency futures contract for delivery on $t_{2}$. This combination of contracts is defined as a synthetic Eurocurrency interest rate futures contract. The price of the synthetic contract will depend on the prices of its constituents. Our concern, however, is not so much with the efficient pricing of the synthetic interest rate futures contract (as there are no actual prices on which to base a comparison) but rather with its hedging effectiveness. Efficient pricing of the synthetic is an important point that we will return to in the concluding section. 


\subsection{The Synthetic Pricing Model}

The replicating portfolio approach that we adopt is completely general and could be applied to construct synthetic Eurocurrency interest rate futures of any maturity. However, in order to simplify the exposition, we will assume that the maturity of the foreign currency borrowing period exactly matches the manrity of the Eurodollar interest rate futures contract.

Assume that at time $t_{0}$, a corporate treasurer is making plans to borrow EuroForeign Currency (FC) at time $t_{1}$ to be repaid at time $t_{2}$. Interest rates are stochastic so that at $t_{0}$, the FC interest rate at $t_{1}$ is uncertain. It is this risk that the treasurer is attempting to hedge.

Figure 1: Synthetic Eurocurrency Interest Rate

Pricing Relationship

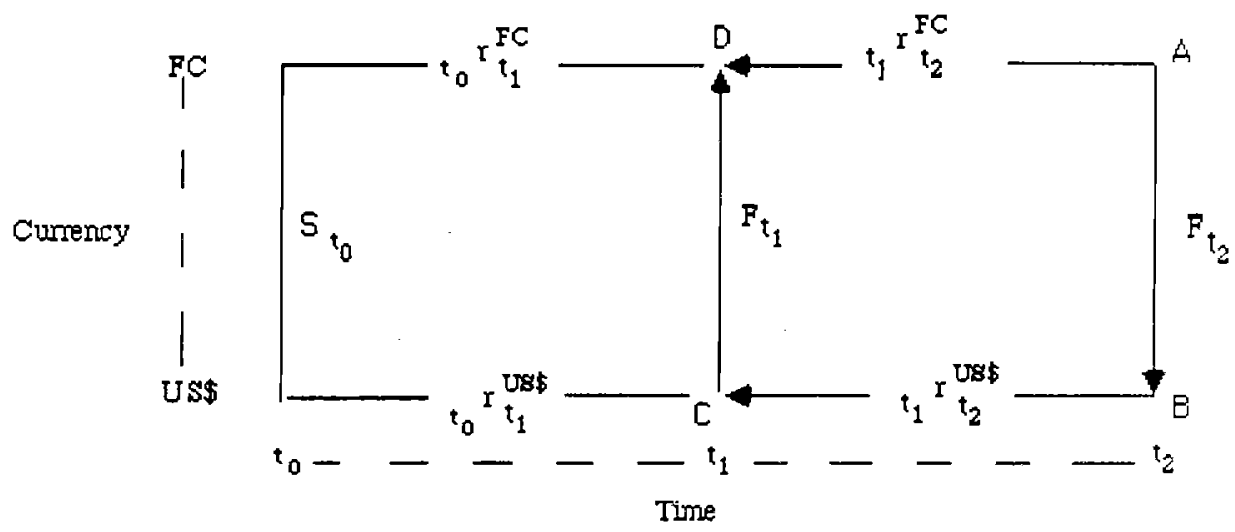

In Figure 1, we depict time along the horizontal dimension and currency along the vertical dimension. Spot and forward exchange rates measure the price of shifting between dollars and foreign currency while interest rates measure the price of shifting cash flows 
across time. The equilibrium relationship between spot and forward exchange rates and interest rates on securities without intervening cash flows is well-known from the interest rate parity theorem. In particular, the rate for a forward transaction on $t_{1}$ is given by

$$
\frac{F_{t_{1}}}{S_{t_{0}}}=\frac{\left[1+4^{r}{ }^{\text {US }} t_{1}^{t_{1}}\right]}{\left[1+4^{r} r_{t_{1}}^{F C}\right]}
$$

and the rate for a forward transaction on $t_{2}$ is given by

$$
\frac{F_{t_{2}}}{S_{t_{0}}}=\frac{\left[1+{ }_{4}{ }^{\text {USS }}{ }^{\text {US }}\right]}{\left[1+{ }_{40}{ }^{r C} t_{2}^{F}\right]}
$$

where

$$
\begin{aligned}
& S_{t_{0}}=\text { Spot exchange rate expressed as US } \$ \text { per foreign currency }(F C) \text { at time } t_{0} \\
& F_{t_{1}}=\text { Forward exchange rate at } t_{0} \text { for delivery at time } t_{1} \\
& F_{t_{2}}=\text { Forward exchange rate at } t_{0} \text { for delivery at time } t_{2} \\
& { }_{0}{ }_{\mathrm{r}_{1}}^{\mathrm{USS}}=\text { US } \$ \text { interest rate for the period } t_{0} \text { to } t_{1} \\
& { }_{0} \frac{\mathrm{T}}{\mathrm{US}} h_{2}=\text { US } \$ \text { interest rate for the period } t_{0} \text { to } t_{2} \\
& { }_{4}{ }_{t_{1}}^{F C}=F C \text { interest rate for the period } t_{0} \text { to } t_{1} \text { and } \\
& 4_{0}^{5} \frac{F C}{F}=F C \text { interest rate for the period to to } t_{2}
\end{aligned}
$$

Noting that when equation (2) is written in terms of implied interest rates, we have 


$$
\frac{F_{t_{2}}}{S_{t_{0}}}=\frac{\left[1+{ }_{t_{0}} r_{t_{1}}^{U S S}\right]\left[1+t_{t_{1}} r_{t_{2}}^{U S \$}\right]}{\left[1+t_{t_{1}} r_{t_{1}}^{F C}\right]\left[1+t_{t_{1}} r_{t_{2}}^{F C}\right]}
$$

where

$$
\begin{aligned}
& t_{1} r_{2}^{U S S}=\text { implied forward Eurodollar interest rate at time } t_{0} \text { for the period } t_{1} \text { to } t_{2} \\
& t_{1} r_{2}^{F C}=\text { implied forward Euro-FC interest rate at time } t_{0} \text { for the period } t_{1} \text { to } t_{2} \text {. }
\end{aligned}
$$

Equating $S_{t_{0}}$ obtained from equation (1) and (3) results in the following relationship

$$
1+{ }_{t_{1}}{ }_{t_{2}}^{F C}=\frac{F_{t_{1}}}{F_{t_{2}}}\left[1+{ }_{t_{1}} r_{t_{2}}^{U S \$}\right]
$$

Notice that equation (4) is analogous to the traditional interest rate parity formula except that the near term cash flows pertain to a future time $\mathrm{t}_{1}$ rather than the present time $\mathrm{t}_{0}$. Equation (4) suggests that the implied forward FC interest rate is closely linked to the implied forward dollar interest rate. Given a quotation on the implied forward dollar interest rate and a term structure of forward exchange rates, the implied forward FC interest rate is determined uniquely.

Quotations on the implied forward dollar interest rate $\left({ }_{t_{1}} r_{t_{2}}^{U S \$}\right)$ are available on a customized basis through banks in the so-called Forward Rate Agreement market. However, quotations on $\left(\mathrm{t}_{1} \mathrm{r}_{\mathrm{t}_{2}}^{\mathrm{USS}}\right)$ are more readily available based on Eurodollar interest rate futures prices. Under the assumption that futures prices (for foreign currency and interest rates) are identical with forward prices, equation (4) can be re-written as

$$
F P^{F C}=\left(F X_{t_{1}} / F X_{t_{2}}\right) F P^{U S \$}
$$


where

$\mathrm{FP}^{\mathrm{FC}}=$ price at $\mathrm{t}_{0}$ for a Euro-FC interest rate futures contract spanning the period

$$
\left[t_{1}, t_{2}\right]
$$

$\mathrm{FP}^{\mathrm{USS}}=$ price at $\mathrm{t}_{0}$ for a Euro- $\$$ interest rate futures contract spanning the period $\left[\mathrm{t}_{1}, \mathrm{t}_{2}\right]$

$F X_{t_{1}}=$ price at $t_{0}$ for foreign currency futures contract for delivery at $t_{1}$

$F X_{t_{2}}=$ price at $t_{0}$ for foreign currency futures contract for delivery at $t_{2}$

In theory, the equivalence between forward contracts and futures contracts is open to question. Forward contracts entail cash flows only upon maturity. Futures contracts on the other hand are marked-to-market daily and intermediate cash flows may result from this daily cash settlement feature. It is well-known [see Jarrow and Oldfield (1981), Cox, Ingersoll and Ross (1981) and Richard and Sundaresan (1981)] that this institutional difference can generate differences between forward and futures prices if the prices on the underlying cash market (for foreign currency or interest rates) are stochastic.

As a practical matter, however, the cash flow risks of futures contracts do not make them strictly inferior since, to some extent, these risks are offset by the greater liquidity in futures markets. And while forward contracts require no initial margin and no intervening cash flows, forward contracts are relatively illiquid and access to the market is somewhat restricted, open only to agents with adequate credit standing to meet cash settlement at maturity only. The relationship between futures and forward contracts is therefore an empirical issue.

A study of the foreign exchange market by Cornell and Reinganum (1981) found that mean differences between futures and forward prices were insignificantly different 
from zero, both in a statistical and economic sense. No similar study exists for the interest rate market as each year there are only four data points of correspondence between implied forward interest rates and the matching interest rates obtained from furures prices.

In view of these findings, we will assume that forward prices and futures prices are on average identical. Equation (5) is our model for pricing the synthetic Eurocurrency interest rate futures contract. In the absence of transactions costs and default risk, our synthetic contract is a perfect substitute for the actual Eurocurrency interest rate futures. The sale of a Eurocurrency interest rate futures contract (line segment AD in Figure1) is replicated by combining the sale of a currency futures contract for date $t_{2}$ (segment $A B$ ) with the sale of a Eurodollar interest rate futures contract (segment BC) and the purchase of a currency futures contract for date $t_{1}$ (segment $C D$ ). In the examples that follow, we will assume that the interval $\left[t_{1}, t_{2}\right]$ is three months. Our other key assumptions are (1) that interest rate parity holds at all times, and (2) that futures prices and forward prices are equivalent.

\subsection{A Numerical Synthetic Hedge Example}

To illustrate the synthetic hedge strategy, consider the case of a West German manufacturing company which will be borrowing DM10 million in the Eurocurrency market and is seeking to protect the rate it must pay. Let the current date be December 15,1985; on March 15,1986 the DM loan will be taken up and it will mature on June 15, 1986. The treasurer of our West German firm could obtain protection against unexpected EuroDM interest rate changes by obtaining a forward rate agreement to lock in the implied forward 3-month EuroDM rate. Assuming that the 6-month and 3-month EuroDM interest rates are currently at $4.75 \%$, the implied forward rate is also $4.75 \%$. This figure represents the cost of the direct approach (segment $\mathrm{AD}$ in Figure 1). 
Altematively, the treasurer could implement our synthetic approach by selling March 86 Eurodollar futures (segment $\mathrm{BC}$ ) and covering the exchange risk by buying the near term, March 86 currency futures (segment $C D$ ) and selling the far term June 86 currency futures (segment AB). ${ }^{5}$ The flow of funds is illustrated in Figure 2.

Figure 2: Example of Synthetic EuroDM Hedge

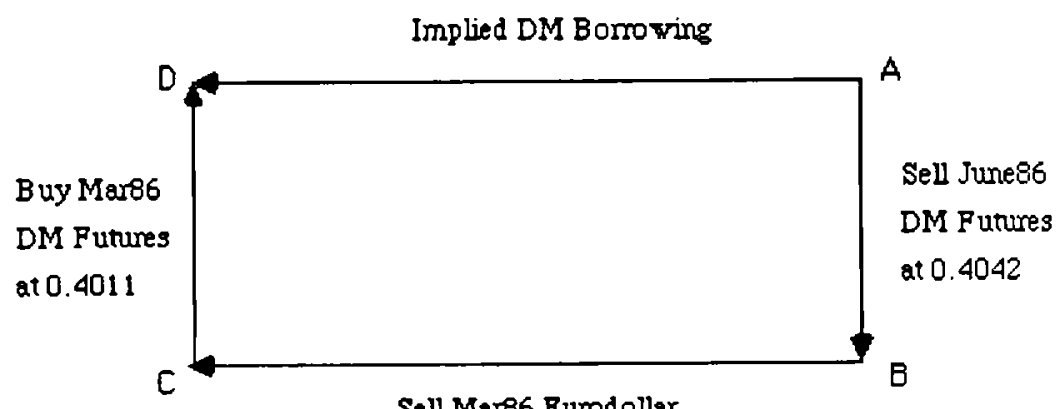

Sell Mar86 Eurodollar

Funures at 92.23

$\frac{1}{\operatorname{Dec} 15,1985 \quad \text { Mar 15, } 1986}$ Jun 15, 1986

We can assess the theoretical DM borrowing rate implied by these futures transactions by using equation (4) and Figure 2.6

5 This combination of buying and selling two futures contracts with different maturities is referred to as a calender spread. As seulement gains and losses for the two currency funres contracts can be netted against each other, the cash flow risks associated with a calender spread are typically less than for an individual contract.

6 Market convention stipulates that short-term interest rates be calculated in simple interest terms, that is, multiplying the annualized interest rate by a factor of $n / 360$ where $n=$ number of days at which deposit is held or borrowed. 
Observed market prices are:

$$
\begin{aligned}
\mathrm{AB} & =0.4042 \$ / \mathrm{DM}=\mathrm{FX}_{\mathrm{t}_{2}} \\
\mathrm{BC} & =[1+0.0777(92 / 360)]=1.019857=\left(1+\mathrm{t}_{1} \mathrm{r}_{\mathrm{t}_{2}}^{\mathrm{US} \$}\right) \\
\mathrm{CD} & =0.4011 \$ / \mathrm{DM}=\mathrm{FX}_{\mathrm{t}_{1}} \\
\text { and so }\left(1+\hat{\mathrm{r}}^{\mathrm{DM}} 92 / 360\right) & =\left(1+{ }_{\mathrm{t}_{1}} \mathrm{r}_{\mathrm{t}_{2}}^{\mathrm{USS}}\right) \mathrm{FX}_{\mathrm{t}_{1}} / \mathrm{FX} \mathrm{t}_{2} \\
& =1.019857(.4011 / .4042)=1.0120350
\end{aligned}
$$

Therefore, $\hat{\mathrm{r}}^{\mathrm{DM}}=4.71 \%$, which represents the effective $\mathrm{DM}$ borrowing rate over the interval March 15 - June 15,1986 constructed using our replicating approach.

In terms of the actual number of futures contracts to trade in, some rounding of the numbers are needed as futures contracts are not traded in fractional amounts.

Jun86 Eurodollar futures:

$$
\frac{\mathrm{DM} 10,000,000 \times 0.4011 \$ / \mathrm{DM}}{\$ 1,000,000 / \text { contract }} \times 92 / 90=4.1(4 \text { contracts })
$$

Mar86 DM currency futures:

$\underline{\mathrm{DM} 10,000,000}=80$ contracts

DM125,000/ contract

Jun86 DM currency futures:

80 contracts $\times \underline{0.4042 \$ / D M}=80.6(81$ contracts $)$

$$
0.4011 \$ / \mathrm{DM}
$$

These futures contracts will be closed out on March 15,1986 when the borrower actually takes delivery of his DM10 million from the Eurocurrency market. Regardless of the 3-month EuroDM interest rate prevailing on March 15,1986, the treasurer has effectively locked in the borrowing cost of $4.71 \%$. This rate holds exactly because the borrowing period that runs from March 15, 1986 to June 15,1986 also corresponds to the maturity of the Eurodollar deposit underlying the Eurodollar futures contract. 


\subsection{The Role of Basis Risk}

Our synthetic futures contract will provide a perfect hedge if there is perfect correlation between the price change in the futures contract and the price change in the anticipated cash transaction. Lack of perfect correlation implies a basis risk. Because of certain institutional features -- that futures contracts are traded only for standardized sizes and mature on only a limited number of dates -- some residual risk is likely to remain when using traded futures contracts to hedge planned cash flows. Our synthetic futures contract will be subject to the same kinds of residual risks when there is a mismatch between one of the fearures of the contract and the features of the underlying cash transactions.

In particular, we want to focus on the maturity of the implied forward interest rate. In our case, even if the maturity of the Eurocurrency contract is 3-months and matches the maturity of the Eurodollar contract, the synthetic contract will result in a perfect hedge only if there are no violations of interest rate parity.

Basis risk may also result when the synthetic hedge is lifted at a time $t_{z}$ prior to the maturity of the futures contracts $t_{1}$. In this case, the correlation between changes in cash and futures prices need not be perfect. While the hedge need not actually be lifted, the situation would correspond to the case of manager who undertook an anticipatory hedge as described above, but was required to report the market values of his positions every week prior to the matuity of his forward contracts. Lack of perfect correlation on a week to week basis would indicate residual risk. 


\section{Empirical Evidence on Hedging Performance}

\subsection{Methodology for Anticipatory Hedges}

In this paper, we use the anticipatory hedge model to examine the hedging performance of synthetic Eurocurrency interest rate futures contracts. ${ }^{7}$ Without loss of generality, we assume that the foreign interest rate hedging problem involves an anticipated cash borrowing of 3-month foreign currency (FC) funds in the Eurocurrency market at an interest rate linked to LIBOR. We assume that the hedger's objective is to minimize the fluctuations in realized borrowing costs denominated in the foreign currency relative to their anticipated values.

Our research design involves two stages. First, we measure the hedging effectiveness of our synthetic contract for hedging interest rate risk for five currencies -Euro-DM, Euro-SFr, Euro-Yen, Eurp-Can\$ and Euro-Sterling. Second, we compare the hedging performance of our synthetic contract with an actual interest rate futures contract (the London International Financial Futures Exchange [LIFFE] 3-month domestic interest rate futures contract) for hedging both domestic sterling and Euro-sterling interest rate risk.

In order to measure hedging effectiveness, we estimate the following regression model

$$
r_{t+k}^{F C}-E\left(r_{t+k}^{F C} \mid \phi_{t}\right)=\alpha+\beta\left(f_{t+k}^{F C}-f_{l}^{F C}\right)+\mu_{\tau}
$$


where

$$
\begin{aligned}
& r_{l+k}^{F C}=\text { the yield on our synthetic foreign currency interest rate futures contract } \\
& E\left(r_{l+k}^{F C} \mid \phi_{l}\right)= \text { the expected foreign currency interest rate in the cash market at time } \\
& \begin{aligned}
t+k, \text { conditional on the information } \phi \text { available at time } t \text { when the } \\
\text { hedge is established and } k=1,2,4 \text { or } 13 \text { weeks and represents the } \\
\text { holding period for the hedge. }
\end{aligned}
\end{aligned}
$$

The coefficient $\_$measures the hedge ratio, defined as the percentage of futures contract to sell per unit of anticipated borrowing. A hedge ratio of unity implies that the naive hedge, matching futures contracts on a one-for-one basis with planned cash positions, is the optimal hedge. The estimated $\mathrm{R}^{2}$ of equation (6) measures the percentage reduction in risk assuming the optimal hedge ratio has been applied. A perfect hedge with no residual risk corresponds to the case with $\mathrm{R}^{2}=1.00$.

To implement equation (3), we use Wednesday settlement prices for Eurodollar and currency futures to calculate a series of synthetic Eurocurrency interest rate futures yields (in annualized terms) based on an underlying 3-month Eurocurrency deposit. This calculation is based on equation (5) modified as follows:

$$
f_{t}^{F C}=\left[\left\{\left(\text { Near }^{\prime} \mathrm{FC} / \mathrm{Far} F C\right)\left(1+\left(\mathrm{f}_{t}^{\$} / 100\right) 1 / 4\right)\right\}-1\right] \times 400
$$

where $f_{t}^{\$}$ is obtained by taking the difference of the Eurodollar futures settlement prices from 100. The 'Near' and Far' FC prices are the settlement prices of the two currency futures contracts that constitute the calender spread expressed in terms of $\$$ per FC.

We calculated the synthetic yields for each of the currencies, $£, D M, S F r$, Yen and Can\$ from June 1982 to August 1986. For the June 1982 series, we use the September 1982 Eurodollar futures and the September 1982 (near) and December 1982 (far) currency 
futures contracts. The contracts are switched when we enter into the delivery month. In the above example, come September 1,1982, the relevant Eurodollar futures contract is the December 1982 contract and the currency futures are the December 1982 and March 1983 ones. There are a number of missing observations as some of the 'far' exchange contracts required for the calendar spread do not trade until the contracts are about eight months from maturity. These missing observations are excluded from the regression.

Eurocurrency rates are only available for $1,2,3,6$, and 12 months and do not permit us to measure the implied 3-month forward rates for most intervals. Consequently, for the short-period hedges, $k=1,2$ and 4 weeks, the spot Eurocurrency offer rates $\left(r_{t} \mathrm{FC}\right)$ are used as proxies for $E\left(\mathrm{r}_{t+\mathrm{k}} \mathrm{FC}_{l \phi_{t}}\right)$. However, the implied 3-month forward rate derived from the 6-and 3-month Eurocurrency cash rates can be used to serve as the corresponding proxy for $\mathrm{E}\left(\mathrm{r}_{\mathrm{t}+\mathrm{k}}^{\mathrm{FC}} \mid \phi_{1}\right)$ in the 13-week hedges.

The empirical work in this paper is conducted within a standard regression framework. The major econometric difficulty in our application is one which is now familiar from the work of Hansen and Hodrick (1980) and others; we have weekly observations but holding periods that go beyond a week (that is, 2-weeks, 4-weeks and 13weeks). The method proposed in Cumby, Huizinga and Obstfeld (1983) has the ability to estimate the covariance matrix of the coefficients consistently when the errors are serially correlated, conditionally heteroscedastic or both. Therefore, we adopt the CHO program based on this methodology to correct for the autocorrelation problem in equation (6) that results from weekly over-lapping observations. ${ }^{8}$

8 CHO refers to the "Two step two stage least squares" computer program, version 2.1 written by Robert Cunby and John Huizinga based on the methodology given in Cumby, Huizinga and Obstfeld (1983). 


\subsection{Data Description}

Interactive Data Corporation (IDC) provided us with data on both Eurodollar and currency futures contracts as well as the 3-month and 6-month Eurocurrency offer rates. The currency furures settlement prices from IDC are given to three decimal places. We believe that having the exchange rates expressed in four decimal places are more appropriate and remedy this with data from the Chicago Mercantile Exchange (CME) Annual Reports, 1982-1986.

Although we have daily data for Eurodollar futures starting from June 1982, we commence our hedging analysis from September 1982 to allow for seasoning of the contract. Wednesday's settlement prices are collected for the nine months preceding the maturity date of each contract for the Eurodollar and currency futures. The prices within the settlement month itself are excluded since contract volume declines rapidly as a contract approaches maturity. Only the near futures contract prices are used for hedging as this contract attracts the highest liquidity and therefore represents the least costly and most efficient contract to use. Data points are excluded for those Wednesdays which are holidays.

Ideally, the prices of the cash and futures interest rates for our regression analysis should be measured at the same instant. Futures settlement prices are given at the close of trading on the International Monetary Market (IMM), 2:00p.m. Chicago time which is 3:00p.m. New York time. The Eurocurrency cash deposit rates obtained from IDC are given by the London branch of the Chase Manhattan bank at the close of the London business day , 12:00 Noon New York time. This gives rise to an approximate three-hour gap. However, there is no reason why closing rates in Chicago should be consistently higher or lower than those in London. This lack of time synchronization should not bias any of our coefficient estimates although this could affect the $R^{2}$ measures. 
The Eurocurrency deposit rates from IDC are indicative of the condition of the Eurocurrency deposit markets on the dates in question. These rates should not be considered as rates at which a trade actually takes place. Data on 3- and 6-month Eurocurrency offer rates ${ }^{9}$ for the deposits, Eurof, EuroDM, EuroSFr are available since January 1982. However, for EuroYen and EuroCan\$ deposits, the series from IDC started only from June 1,1982. Therefore, the entire sample for the EuroCan\$ and EuroYen synthetic hedges covers a shorter period from September 1982 to November 1986. We commence the hedging analysis from September 1982 in order to allow for the three months of data required for calculating the implied forward rates .

Finally, we also obtained data from IDC on the settlement prices of the LIFFE domestic sterling interest rate futures and the offer rates of the interbank domestic sterling deposits. These data series commenced from December 1982 , but we compare this contract's hedging performance with that of the synthetic Eurof interest rate futures contract commencing March 1983 to allow once again for seasoning.

\subsection{Empirical Results for Synthetic Interest Rate Futures Contracts}

Before presenting our results, it may be useful to consider what an appropriate benchmark would be for gauging the success of our synthetic contract. In this respect, Black (1986) has argued that the success of a new futures contract depends heavily on its ability to provide superior hedging capabilities relative to alternative vehicles. The results of using Eurodollar futures contracts alone as a cross-hedge for non-dollar Eurocurrency interest rate risk have been reported by Koh (1988). For the five Eurocurrencies analyzed here, hedging effectiveness as measured by $\mathrm{R}^{2}$ was most often under $10 \%$, with the exception of the Canadian dollar, where the $\mathrm{R}^{2}$ for the 13-week holding period reached

9 In addition to the 3-month rates, 6-month rates are needed in order to compute the implied forward interest rates for use in 13-week hedges. 
$70 \%$. The latter result is somewhat surprising but illustrates the close correlation between U.S. and Canadian dollar interest rates.

Another benchmark might be the hedging effectiveness of the Eurodollar interest rate futures contract itself to hedge Eurodollar interest rate risk. These results are presented in Table 1 for our total sample period. The results indicate a level of hedging effectiveness that rises steadily as the holding period increases from one to thirteen weeks. At the 13week period, the optimal hedge ratio is not significantly different from unity and the $R^{2}$ is near $90 \%$. Our finding that the Eurodollar futures contract is not a perfect hedge at the 13week horizon may in part reflect the lack of time synchronization in the data and the cash flow risk associated with interim furures price changes, factors that will also affect our analysis of the synthetic contracts.

Our results on the synthetic futures contracts are presented in Tables 2-6, one table per currency. In each case, the sample period is divided into two subperiods (I and II) of approximately equal size. Because the foreign exchange value of the dollar went through a turbulent period, peaking in February 1985, we also make a second subdivision with observations from October 1982 - February 1985 as subperiod I' and March 1985 November 1986 classified as subperiod $\mathrm{II}^{1}{ }^{10}$

Further insights into our results may be revealed by noting that the hedge ratio is equivalent to the covariance between futures and cash price changes scaled by the variance in futures prices, while hedging effectiveness $\left(R^{2}\right)$ is equal to the square of the covariance between futures and cash price changes divided by the variance of each factor. Table 7 provides an overall picture of how covariance and variance measures of daily changes in

10 The second subdivision begins from October 1982 to allow for the effects of the Fed change in targeting policy to affect all sample observations equally. 
cash and futures prices have changed over the sample period. Note that the synthetic futures rates for all currencies are more volatile than the cash rates.

\section{Synthetic EuroSterling Hedge}

Table 2 gives the results for the synthetic Euro-sterling contract. For the entire sample period, hedging effectiveness measured by $\mathrm{R}^{2}$ rises steadily as the holding period increases and reaches $84 \%$ for the 13 -week holding period. This figure is only slightly smaller than the $90 \%$ figure reported for the Eurodollar contract in Table 1. For the 13week period, the optimal hedge ratio is not significantly different than unity.

Comparing subperiod I and II, we find that hedging effectiveness is higher in subperiod I, and with the exception of the 13-week holding period, the hedge ratios are also higher in subperiod I. However, under our second subdivision, the results tend to show higher hedging effectiveness and hedge ratios closer to unity in the subperiod II'. From Table 7, we see that the variance of Euro-sterling interest rates increased in 1985. Therefore, despite the higher covariance between cash and furures prices, hedging effectiveness changed only slightly.

\section{Svnthetic EuroCanadian Dollar Hedge}

Tuming to the EuroCan\$ deposit in Table 3, once again we observe that the hedge ratios and measures of hedging effectiveness are positively related to the holding periods. For the entire sample period, the $\mathrm{R}^{2} \mathrm{~s}$ increase progressively from .51 at the 1 -week holding period to .88 at the 13 -week holding period. The latter figure is very near the hedging effectiveness of the Eurodollar contract in hedging dollar risk. For the 13-week period, the optimal hedge ratio is not significantly different from unity.

Viewing the parameters in terms of subperiods I and II indicate that the $\mathrm{R}^{2} \mathrm{~s}$ are slightly higher in subperiod II than in subperiod 1 (with the exception of the 13-week 
hedge). Generally, for the EuroCan\$ deposit, the hedge ratios between the two subperiods differ by an average .06 and $R^{2}$ s by an average .07 across all hedge lengths. Also, for both subperiods, the 13-week hedge ratios are not significantly different from the naive hedge ratio of one.

However, in terms of the second subdivision based on the relative strength of the dollar, most of the hedge ratios across all hedge lengths for both subperiods I' and II' are not significantly different from one. Furthermore, the $R^{2} s$ are slightly lower in subperiod II' in comparison to subperiod I'. While the covariance between changes in EuroCan\$ cash and synthetic EuroCan\$ futures rates increased over 1985 and 1986, the volatilities of both cash and futures rates have increased.

\section{Synthetic EuroDeutsche Mark Hedge}

For the entire sample period, it appears that the hedging effectiveness of the synthetic hedge for the EuroDM hedge is not as impressive as that of the EuroSterling and EuroCan\$. From Table 4(a), we observe $\mathrm{R}^{2}$ s for 2-week and 13-week hedges of .19 and $.56 .{ }^{11}$ However, examining the results by subperiods allows us to have a better understanding of the potential hedging effectiveness of the EuroDM synthetic hedge.

We observe that subperiod I is characterized by much higher residual risk for the synthetic DM hedge than is the case in subperiod II. For example, the 13 -week $R^{2}$ of .81 in subperiod II is almost double that of .48 registered in subperiod I. For 2-week and 4-week hedges, the $\mathrm{R}^{2}$ increases are almost three-fold from one subperiod to another. This takes place despite the greater volatility of US\$/DM exchange rates in 1985 and 1986 (annualized volatilities of $15 \%$ and $13 \%$ ) compared to the average volatility of $10 \%$ from $1982-1984$.

11 While the Eurodollar cross-hedge gives .17 and.43 as the corresponding numbers. 
From Table 7, we see that the variance for changes in EuroDM cash and synthetic futures rates declined progressively over the years. Both cash and futures interest rates' volatilities peaked in 1983 with cash rates' volatility getting lower faster while futures rates' volatility decline at a slower rate given the higher volatilities of the US\$/DM exchange rate in 1985 and 1986. The improvement in hedging effectiveness for the 13-week hedge in subperiod $I$ is due to that fact that the volatility of the synthetic futures rates register a large drop going from 1983 to 1984 .

When we examine the hedge ratios under the second subdivision, only 1-week and 2-week hedge ratios in subperiod I' are significantly different from one. All the remaining hedge ratios however are not very far from the naive hedge given the decline in EuroDM futures volatility. On the whole, hedging effectiveness improves across all hedge horizons under the second subdivision and interestingly, the $\mathrm{R}^{2}$ measures are not sensitive to foreign exchange trends, giving about the same values regardless of whether the U.S.dollar is appreciating or depreciating. The covariance between changes in EuroDM cash and futures rates declines in 1983 and 1984 with the highest covariance reported for 1985. This suggests that the greater coordination between US and German interest rate policies during the latter half of the sample period resulted in a closer relationship between EuroDM cash and synthetic EuroDM futures rates. This also contributes to the higher hedge ratios reported in subperiod II'.

\section{Synthetic EuroSwiss Franc Hedge}

While the results reported in Table 5 on the EuroSFr hedge over the entire sample period may represent an improvement over that of cross-hedging with Eurodollar futures, the $R^{2} s$ do not appear too impressive. But the picture is again different when viewed across subperiods. 
Under the first subdivision, subperiod II's $\mathrm{R}^{2}$ measure for the 13-week hedge of .45 is almost double that of subperiod I's while for 2- and 4-week hedges, the improvements are about three and half times. The US\$/SFr exchange rate was the most volatile among exchange rates and this certainly affected the volatility of the synthetic EuroSFr futures interest rates. In fact, changes in both EuroSFr cash and futures rates had higher variances in the first half of the sample period than the later half. This helps to explain the improvement in hedging effectiveness during subperiod II.

When the subdivision is based on the relative strength of the US\$, the $R^{2}$ s of the 1-, 2- and 4-week hedges show little change. On the other hand, the 13-week hedge again showed an improvement with $R^{2}$ at .53 in subperiod II' compared to an $R^{2}$ of .30 in subperiod I'. Also, the hedge ratio derived from this hedge is the only one for the Euro-SFr that is not significantly different from one.

The relatively high basis risks in the EuroSFr hedges as compared to that of the other currencies can be explained in terms of the much lower cash to futures market linkage as well as the higher volatility of the futures rates. While volatility has declined over the past few years, the covariance have not changed. The covariance between the daily changes in EuroSfr cash rates and the synthetic EuroSFr rates was in fact higher in the early part of the sample period and declined over 1985 and 1986, but the $R^{2} s$ still improve due to lower volatilities of both cash and futures rates.

Levich (1982) found that in tests of interest rate parity for three-month Euro-Swiss Franc deposits over $20 \%$ of the observations appear to lie outside the stated no-arbitrage boundaries of $.25 \%$. Of course, if traders have transactions costs in excess of $.25 \%$, then the bounds are too low. However, it would appear that the deviations from interest parity are higher during periods of higher volatility in both Swiss franc interest rates and exchange rates. Therefore, the better hedging performance of the synthetic EuroSfr furures 
over the last two years of our sample period may also be attributed to more efficient pricing of the synthetic contract in accordance with interest rate parity.

\section{Synthetic EuroJapanese Yen Hedge}

Finally, in Table 6, we present the results of the synthetic EuroYen hedges.

Clearly, over the whole sample period, the synthetic hedges do better than using Eurodollar furures alone to hedge the fluctuations in EuroYen borrowing costs. While the $\mathrm{R}^{2}$ for the 13-week hedge is only .38 for the whole sample period, the results in terms of subperiods are more encouraging.

From Table 6(c), we observe that for the 4-week and 13-week hedges, $R^{2} \mathrm{~s}$ of .50 and .61 in subperiod $\Pi$ are significantly higher than the corresponding figures of .07 and .14 measured in subperiod I. A number of important changes in regulations governing the Japanese financial market were instituted immediately before and during subperiod II. 12 All these changes were in the direction of relaxing controls over the participation by foreign banks and non-residents in the EuroYen market. It could be argued that these moves allowed for greater liquidity in the EuroYen deposit market and contributed to the higher hedging effectiveness measures of the synthetic EuroYen hedges. The hedge ratios are also higher in subperiod II attesting to the increased covariance of cash and futures rates in the EuroYen markets. The higher $\mathrm{R}^{2} \mathrm{~s}$ and hedge ratios were also reinforced by the decreasing volatility of the synthetic EuroYen futures rates.

When hedging effectiveness is examined under the second subdivision, for all hedge lengths, the $\mathrm{R}^{2}$ measures in subperiod II' are again higher than those in subperiod I'. The 13-week $R^{2}$ of .69 is an improvement of about four and half times and the 4-week $R^{2}$ of .55, a six times increase in hedging effectiveness in comparison to subperiod I'.

12 See Occasional Paper 43, Intemational Capital Markets - Developments and Prospects published by the IMF, February 1986. 
As for the hedge ratios, the hedges in subperiods I and I' are accompanied by such high basis risks (low $\mathrm{R}^{2} \mathrm{~s}$ ) that for the 1- and 2-week hedges, it is preferable to remain unhedged since the hedge ratios are not significantly different from zero. Reflecting the hedging effectiveness increase, the hedge ratios in subperiod II are also higher, and all of them are significantly different from one. Thus, underhedging is preferred to a naive hedge. Under the second subdivision, only the 13 -week hedge ratio .93 in subperiod I' is not significantly different from one. The 13 -week hedge ratio of .80 in subperiod II' represents a less costly hedge (less futures needed to be sold) and in addition, results in higher hedging effectiveness. Therefore, the synthetic EuroYen hedge has been increasingly effective after 1985.

\section{Stability of Regression Parameters}

Table 7 presents an overall picture of how covariance and variance measures of daily changes in cash and futures rates have changed over time. The hedge ratios can be expressed in terms of the covariance of changes in cash and futures rates divided by the variance of changes in futures rates. Our estimated $R^{2}$ is the squared covariance divided by the variance of changes in cash rates and the variance of changes in futures rates. The synthetic futures rates for all the currencies are more volatile than the cash rates. By definition, the estimated hedge ratio and hedging effectiveness will vary with changes in these covariance and variance measures.

To examine the stability of the slope and intercept coefficients over the two subdivisions for all the synthetic hedges, we perform a dummy variable test as in the following equation

$$
r_{t+k}^{F C}-E\left(r_{t+k}^{F C} \mid \phi_{t}\right)=\alpha+\beta_{1}\left(f_{t+k}^{F C}-f_{t}^{F C}\right)+\beta_{2} D_{1}+\beta_{3}\left[D_{1}\left(f_{t+k}^{F C}-f_{t}^{F C}\right)\right]+\mu_{t}
$$


where

$$
\begin{aligned}
D_{1} & =1 \text { for subperiod I } \\
& =0 \text { for subperiod II. }
\end{aligned}
$$

The relevant standard errors and $W$ ald statistic ${ }^{13}$ that tests $\hat{\beta}_{2}=\hat{\beta}_{3}=0$ are given in Table 8. The results confirm our observations made earlier. All of the Wald statistics across all currencies and hedge horizons reject the equality of the joint hypothesis $\hat{\beta}_{2}=\hat{\beta}_{3}=0$.

In the case of the EuroSterling and EuroCan $\$$ synthetic hedges, the $\mathrm{R}^{2} \mathrm{~s}$ arrived at allowing for changes in parameters are only 1-2 percentage points higher than the $R^{2} s$ obtained in Tables 2(a) and 3(a). Except for $\hat{\beta}_{3}$ in the case of the 1-week synthetic EuroSterling hedge, for all other hedge lengths, the $\hat{\beta}_{2}$ s and $\hat{\beta}_{3}$ s are not individually significantly different from zero. Although the Wald statistics show that they are jointly significant.

On the other hand, for EuroDM, EuroSFr and EuroYen synthetic futures, parameter shifts play a more important role. First, for the EuroDM deposit, the $\mathrm{R}^{2} \mathrm{~s}$ across all hedge lengths improve by 3-4 percentage points when parameter shifts are allowed. Furthermore, in three out of four hedge horizons, the slope coefficient changes are significant implying that the relationship between changes in the EuroDM cash rates and the synthetic futures rates differ over the two subperiods. We know that the volatilities of both US\$/DM exchange rate futures and Eurodollar futures increased in subperiod II as compared to that in subperiod I. Therefore, we can safely conclude that the higher slope coefficients for subperiod II hedges are a result of an increase in the covariance measure that surpasses the variance increases.

In the case of the EuroSFr deposit, we find that only the slope coefficient shift for the 2-week hedge is individually significant. The $\mathrm{R}^{2}$ measures are only slightly better than

13 The Wald statistic is distributed as an F-statistic. 
the ones shown in Table 5(a). It appears that market imperfections are present that prevent the EuroSFr interest rates from being closely related to the synthetic EuroSFr futures yields.

Finally, as expected, incorporating shifts in the intercept and slope parameters results in significantly higher $\mathbf{R}^{2} \mathbf{s}$ for the synthetic EuroYen hedge. Across all hedge lengths, hedging effectiveness improves by 7 to 19 percentage points. Furthermore, all the slope coefficients $\left(\hat{\beta}_{3} s\right)$ are significantly higher in subperiod II. It could be argued that the relaxation of controls over activities in the EuroYen market resulted in a closer alignment of the synthetic EuroYen furures rates to the EuroYen cash rates.

\subsection{Comparison of Synthetic Eurof Futures with LIFFE Domestic $\mathfrak{f}$ Futures}

The underlying instrument of the LIFFE domestic sterling interest rate futures is the 3-month sterling deposit in the London interbank market. Our synthetic EuroSterling futures contract, is designed to hedge the 3-month EuroSterling deposit. In this section, we analyze the hedging performance of the two contracts in terms of hedging both domestic Sterling deposit and EuroSterling deposit offer rates. These results are given in Tables 9 12 divided according to holding periods. We start the hedging analysis for identical periods from March 1983 to November 1986 in order to allow the LIFFE contract a seasoning period. In this case, the $\mathrm{R}^{2}$ measures are directly comparable across contracts as the dependent variables are the same.

Taking the domestic Sterling deposit as the cash instrument shows that the LIFFE contract narrowly but consistently outperforms the synthetic contract The difference in $\mathrm{R}^{2}$ is $12 \%$ for the 1 -week hedge, $8 \%$ for the 2 -week hedge, $9 \%$ for the 4 -week hedge and only $4 \%$ for the 13-week hedge over the whole sample period. The higher $R^{2} \mathrm{~s}$ in favor of the LIFFE domestic Sterling interest rate futures contract are to be expected since the synthetic contract represents a cross hedge in comparison. When the cash instrument is the 
EuroSterling deposit, the LIFFE contract also performs better consistently. However, this time, the difference in hedging effectiveness averages only about $5 \%$ in favor of the LIFFE domestic Sterling interest rate futures. To measure the significance of these results, we use an F-test suggested by Black (1986) :

$$
\begin{aligned}
F & =\frac{\text { Residual Risk of Synthetic Sterling Futures }}{\text { Residual Risk of LIFFE Sterling Futures }} \\
& =\left(1-R^{2}\right) S_{y n} /\left(1-R^{2}\right) \text { LIFFE }
\end{aligned}
$$

The F-statistics in Table 13 show that only for one case (the 4-week hedge) is it possible to reject the null hypothesis $\mathrm{H}_{0}:\left(1-\mathrm{R}^{2}\right) \mathrm{Syn}=\left(1-\mathrm{R}^{2}\right) \mathrm{LIFFE}$ at the $5 \%$ significance level. ${ }^{14}$ With this exception, the results confirm that the hedging effectiveness of the LIFFE contract and the synthetic contract are not statistically different. The decision to use the LIFFE Eurosterling contract or the synthetic contract would depend on other economic factors, in particular contract prices and transaction costs. The synthetic contract involves Eurodollar and currency futures contracts that trade in deeper and more liquid markets which may be subject to less mispricing in comparison to the LIFFE contract. However, transaction costs will be greater for the synthetic contract, perhaps by about $\$ 137$ per synthetic contract (See Table 14). At $\$ 25$ per basis point in contract price, $\$ 137$ represents 5.48 basis points. Holding hedging effectiveness fixed, a synthetic contract would need to be priced 5.48 basis points more favorably to be competitive with the LIFFE contract.

The subperiod hedging performance of the LIFFE domestic sterling interest rate futures contract and that of the synthetic Eurosterling interest rate futures are also interesting. For the LIFFE contract, $\mathrm{R}^{2} \mathrm{~s}$ in subperiod II are generally higher than the ones

14 The critical value of $F(184,184)$ at the $97.5 \%$ confidence level (for 2 -tailed test) is 1.336 . 
in subperiod I. For the 13-week hedge on domestic sterling cash deposit, $\mathrm{R}^{2}$ increases from .70 to .86 ; when the underlying cash instrument is the Eurosterling deposit, $\mathbf{R}^{2}$ increases from .62 to. 87 .

Likewise for the synthetic Eurosterling interest rate futures, hedging performance improves in the second half of the sample period. When the underlying deposit is the domestic sterling deposit, the synthetic cross hedge $\mathrm{R}^{2}$ for the 13 -week holding period increases from .62 in subperiod I to .83 in subperiod II. For the Eurosterling cash deposit, $\mathrm{R}^{2}$ also improves from .61 to .84 moving from subperiod I to subperiod II.

All these results speak well of the hedging performance of the synthetic Eurosterling interest rate futures. However, the market is the best judge of a furures contract's success. We suspect that the LIFFE domestic sterling futures contract ${ }^{15}$ manages to succeed because it meets the direct hedging function on domestic sterling deposits and the cross hedging function on Eurosterling deposits more cost effectively than the next best alternative, the synthetic Eurosterling contract.

15 LIFFE reported the following figures for their domestic Sterling futures contract. In early 1986, volume averaged aound 50,000 contracts per month (2,500 per day) and in January 1989 , this had grown to 400,000 contracts per month $(20,000$ per day $)$. 


\section{Conclusions and Policy Implications}

Our purpose in this paper was to show that, despite the absence of specific instruments for hedging non-dollar interest rate risk, an effective way for managing this risk has been feasible using readily available futures contracts. We have demonstrated that, in theory, it is possible to replicate a Eurocurrency interest rate futures contract using Eurodollar interest rate futures in conjunction with currency futures. In principle, our proposed synthetic contract perfectly mimics the cash flows of a true, Eurocurrency interest rate futures contract. In practice, the limited availability of Eurodollar futures at all maturity dates, the fixed size of available contracts, and deviations from Interest Rate Parity in the currency futures market may make our synthetic contract an imperfect substitute for a true Eurocurrency interest rate futures. However, given that the deviations from Interest Rate Parity are likely to be extremely small, our synthetic contract should hold considerable promise for corporations with large positions denominated in Eurocurrency interest rates, and for which the terms on these positions float continuously vis-a-vis the Eurocurrency LIBOR rate.

The empirical evidence presented in this paper shows that with the greater integration and liberalization of financial markets there is increasing potential for higher hedging effectiveness in the synthetic futures contracts. For the latter half of our sample period, the 13-week $R^{2}$ measures for the synthetic EuroSterling futures and that of the EuroCanadian dollar futures are both as high as .83 . The respective hedge ratios of 1.02 and 1.01 are both not significantly different from the naive hedge. For the synthetic EuroDeutsche mark futures, the 13-week hedging effectiveness measure reported that $81 \%$ of the cash market risk is eliminated, although the presence of higher basis risk resulted in a hedge ratio of .71 , which is significantly less than one. The synthetic EuroYen futures performance is also exceptional with a 13-week $\mathrm{R}^{2}$ measuring .61 and a commensurate hedge ratio of .76 , once again suggesting that underhedging is optimal. The least effective 
results are for the EuroSwiss franc synthetic hedge. For the 13 -week hedge, only $45 \%$ of the cash market risk is reduced by hedging with a hedge ratio of .56 reflecting the higher amount of basis risk present.

We also compared the hedging performance of the synthetic EuroSterling futures with that of the LIFFE domestic Sterling futures contract. The differences in 13-week $\mathrm{R}^{2} \mathrm{~s}$ are extremely small. Both contracts eliminated over $80 \%$ of the risks present in a portfolio of futures and cash deposits, whether the cash deposit rate is that of a domestic sterling deposit or an Eurosterling deposit.

In recent months, several Eurocurrency interest rate futures contracts have been introduced on exchanges around the world -- a Euro-French franc contract in Paris (MATIF, September 1988), a Euro-DM contract in London (LIFFE, April 1989), and a Euro-Yen contract in Tokyo (TIFFE, June 1989). In July 1989, the Chicago Mercantile Exchange introduced the DIFF contract, the price of which depends on the interest differential between the three-month Eurodollar and a three-month Eurocurrency rate. Another synthetic Eurocurrency interest rate futures could be constructed by combining a Eurodollar interest rate futures with a DIFF contract.

Notwithstanding these recent developments, the research reported here suggests several important implications for the future of international financial markets and for the development of corporate financial policies. First, as far as government policymakers are concerned, our synthetic Eurocurrency interest rate futures contract represents yet another example of how financial innovation allows agents to circumvent market controls or redress a market failure. The slow development of true, non-dollar interest rate futures markets has very likely encouraged agents to consider the types of synthetic arrangements we have described. Artificial impediments to the development of non-dollar interest rate futures 
markets may have simply altered the locus of trading and the specifics of the contracting, without actually halting the hedging or speculation on non-dollar interest rate movements.

Statistics from the Chicago Mercantile Exchange reveal that in the 1981-1985 period, more than $25 \%$ of the open interest in Eurodollar futures was attributed to non-US based commercial banks. ${ }^{16}$ It is not possible to know exactly why these transactions occured. They may reflect attempts to manage risks associated with dollar or Eurodollar positions held by foreigners. But they also may reflect an attempt to manage non-dollar interest rate risks in the manner in which we have suggested. ${ }^{17}$

Second, from the standpoint of corporations or portfolio managers, our theoretical pricing model clearly shows how synthetic contracts can be constructed even for currencies without an actual Euro-interest rate futures contract. Managers with interest rate exposure in Australian dollars, Belgian francs, Italian lire, ECU, and so forth may find synthetics a useful risk management tool.

Third, the synthetic approach raises possibilities for commercial and investment banks. Banks could construct synthetic contracts to hedge their own non-dollar interest rate risk, or offer synthetic contracts for sale to clients. Banks could also attempt to earn arbitrage profits by monitoring price differences between existing interest rate futures contracts (or implied forward interest rates) and synthetic prices. It appears as though at least a $5-6$ basis point spread would be necessary to induce arbitrage.

Fourth, the rapid development of new financial products and financial marketplaces raises the issue of whether a true Eurocurrency and foreign currency interest rate futures contract will soon be developed. As Black(1986) has argued, for a futures contract

16 Calculated from data in the Bank for International Seulements (1986) report page 146.

17 Rombach and Walsh (1988) describe an example using the cash Eurocurrency market and foreign exchange forward contracts to hedge foreign currency interest rate risk. 
to be successful, it must fill a gap -- it must provide a new, or more cost effective mechanism for hedging risks that previously was not satisfied. For the new contracts at LIFFE, MATIF, and TIFFE to succeed, they must compete with syntherics of two types -the one described in this paper and another built around the CME's DIFF contract. Our analysis demonstrates that the former synthetic contracts offer an effective means (and in some cases, very highly so) for hedging Eurocurrency interest rate risk. Furthermore, the individual components of our synthetic contract are well-known for trading in deep and liquid markets that encourage accurate pricing. The lack of true futures contracts for nondollar Eurocurrency interest rates in this sitriation may not represent a market failure and may not represent a profitable, new contract for an exchange to develop.

An analogy can be drawn to the market for 'cross-rates' in the foreign exchange market. With $\underline{\mathrm{N}}$ currencies in the world, there are $\left(\mathrm{N}^{2}-\mathrm{N}\right) / 2$ bilateral exchange rates. (With $\mathrm{N}=150$ countries, however, the total is 11,175 bilateral exchange rates.) In practice these markets are served by the $(\mathrm{N}-1)$ individual exchange rates of each currency vis-a-vis the U.S. dollar. ${ }^{18}$ A transaction between, for example, the Swedish Kroner (SK) and the Mexican peso (MP) is done indirectly using SK/\$ and \$MP quotations and exchanges. The U.S. dollar here serves the role of a vehicle currency; the two transactions involve lower liquidity risks and transaction costs than a single direct exchange in the SKMP market. The absence of a separate SK/MP foreign exchange market is not a market failure, but an optimal response to the cost of establishing and maintaining the SKMP market relative to the synthetic, indirect approach.

In a similar fashion, Euro-dollar and currency futures contracts may play a role as "vehicle instruments," allowing agents to construct synthetic Eurocurrency interest rate furures at low cost. The demand for a true Eurocurrency interest rate futures market would

18 The Deutsche mark/Pound sterling cross rate is one exception. 
depend on a comparison with the pricing, transaction costs and hedging effectiveness of synthetic contracts. In this paper, we have focused on one of those attributes, hedging effectiveness. Our results suggest that on this basis the synthetic contract may often be a highly effective substitute for actual interest rate futures contracts.

Contract pricing and transactions costs are also important determinants of the success or failure of a new product. From our analysis (in Table 14) it is clear that the CME's DIFF contract is equivalent to a jumbo calendar spread -- a porffolio of many nearterm and far-term forward exchange contracts. However, even though the DIFF contract is redundant, it may offer substantial savings in terms of transaction costs. A clearer picture of the role of synthetic interest rate futures will emerge once our analysis is extended to include pricing and transaction cost considerations. 
Table 1: Eurodollar Direct Hedge Results

(a) Entire Sample (Jun 9,1982-Nov 26,1986)

$\begin{array}{lccc}\text { Holding Period } & \mathrm{N} & \hat{\beta} \text { (Standard Error) } & \mathrm{R}^{2} \\ \text { 1-week } & 234 & .7953(0.03634)^{* \#} & .6761 \\ \text { 2-week } & 234 & .8161(0.03833)^{* \#} & .7340 \\ \text { 4-week } & 234 & .8342(0.04217)^{* \#} & .7764 \\ \text { 13-week } & 234 & 1.0351(0.03479)^{*} & .8999\end{array}$

(b) Subperiod I (Jun 9,1982-Aug 29,1984)

$\begin{array}{lccc}\text { Holding Period } & \mathrm{N} & \hat{\beta} \text { (Standard Error) } & \mathrm{R}^{2} \\ \text { 1-week } & 117 & .8436(0.04956)^{* \#} & .7192 \\ \text { 2-week } & 117 & .8680(0.05305)^{* \#} & .7677 \\ \text { 4-week } & 117 & .8663(0.09058)^{* \#} & .7810 \\ \text { 13-week } & 117 & 1.0608(0.04327)^{*} & .9212\end{array}$

(c) Subperiod II (Sep 5,1984-Nov 26,1986)

$\begin{array}{lccc}\text { Holding Period } & \mathrm{N} & \hat{\beta} \text { (Standard Error) } & \mathrm{R}^{2} \\ \text { 1-week } & 117 & .6329(0.05422)^{* \#} & .5356 \\ \text { 2-week } & 117 & .6593(0.05369)^{* \#} & .6438 \\ \text { 4-week } & 117 & .7262(0.06102)^{* \#} & .7012 \\ \text { 13-week } & 117 & 1.0231(0.05795)^{*} & .8671\end{array}$

* Significantly different from zero at $5 \%$ level \# Significantly different from one at $5 \%$ level 
Table 2 : Synthetic Hedge Results - EuroSterling Deposit

(a) Entire Period (Jun 9,1982 - Nov 26,1986)

$\begin{array}{lccc}\text { Holding Period } & \mathrm{N} & \hat{\beta} \text { (Std. Error) } & \mathrm{R}^{2} \\ \text { 1-week } & 225 & .5175(.05613)^{* \#} & .3031 \\ \text { 2-week } & 224 & .6819(.05054)^{* \#} & .5034 \\ \text { 4-week } & 224 & .7837(.06200)^{* \#} & .5504 \\ \text { 13-week } & 222 & .9708(.03998)^{*} & .8391\end{array}$

(b) Subperiod I (Jun 9,1982 - Aug 29,1984)

$\begin{array}{lccc}\text { Holding Period } & \mathrm{N} & \hat{\beta} \text { (Std. Error) } & \mathrm{R}^{2} \\ \text { 1-week } & 112 & .6646(.08027)^{* \#} & .3937 \\ \text { 2-week } & 113 & .7874(.06955)^{* \#} & .5670 \\ \text { 4-week } & 113 & .8846(.08656)^{*} & .6003 \\ \text { 13-week } & 114 & .8975(.05393)^{*} & .8303\end{array}$

(c) Subperiod II (Sep 5,1984 - Nov 26,1986)

$\begin{array}{lccc}\text { Holding Period } & \mathrm{N} & \hat{\beta} \text { (Std. Error) } & \mathrm{R}^{2} \\ \text { 1-week } & 112 & .4023(.09813)^{* \#} & .2272 \\ \text { 2-week } & 111 & .6069(.07343)^{* \#} & .4535 \\ \text { 4-week } & 111 & .7358(.08884)^{* \#} & .5242 \\ \text { 13-week } & 108 & 1.0196(.06198)^{*} & .8254\end{array}$

(d) Subperiod I' (Oct 6,1982 - Feb 27,1985)

$\begin{array}{lccc}\text { Holding Period } & \mathrm{N} & \hat{\beta} \text { (Std. Error) } & \mathrm{R}^{2} \\ \text { 1-week } & 120 & .5149(.08326)^{* \#} & .2692 \\ \text { 2-week } & 120 & .7008(.06096)^{* \#} & .5451 \\ \text { 4-week } & 120 & .6590(.05806)^{* \#} & .6087 \\ \text { 13-week } & 120 & .8395(.04975)^{* \#} & .8153\end{array}$

(e) Subperiod II' (Mar 6,1985 - Nov 26,1986)

Holding Period N

1-week

2-week

4-week

13-week
$\mathrm{N}$
88
87
87
85 $\hat{\beta}$ (Std. Error)

$.7805(.10064) * \#$

$.8761(.11195)^{*}$

$.8546(.12566)^{*}$

$.8193(.05688)^{* \#}$
$\mathrm{R}^{2}$

.4248

.4852

.5012

.8312

* Significantly different from zero at $5 \%$ level.

\# Significantly different from one at $5 \%$ level. 
Table 3 : Synthetic Hedge Results - EuroCanadian Dollar

(a) Entire Period (Sep 1,1982 - Nov 26,1986)

$\begin{array}{lc}\text { Holding Period } & \mathrm{N} \\ \text { 1-week } & 213 \\ \text { 2-week } & 212 \\ \text { 4-week } & 212 \\ \text { 13-week } & 212 \\ \text { bperiod I (Sep1,1982 - Oct 10,1984) }\end{array}$

$\begin{array}{lccc}\text { Holding Period } & \mathrm{N} & \hat{\beta} \text { (Std. Erтor) } & \mathrm{R}^{2} \\ \text { 1-week } & 107 & .5474(.05802)^{* \#} & .4549 \\ \text { 2-week } & 107 & .5772(.04981)^{* \#} & .6191 \\ \text { 4-week } & 107 & .6049(.06549)^{* \#} & .6031 \\ \text { 13-week } & 107 & .9507(.04297)^{*} & .8961\end{array}$

(c) Subperiod II (Nov 17,1984 - Nov 26,1986)

$\begin{array}{lccc}\text { Holding Period } & \mathrm{N} & \hat{\beta} \text { (Std. Error) } & \mathrm{R}^{2} \\ \text { 1-week } & 104 & .5831(.04956)^{* \#} & .5710 \\ \text { 2-week } & 104 & .6441(.05796)^{* \#} & .6392 \\ \text { 4-week } & 105 & .7607(.07310)^{* \#} & .6778 \\ \text { 13-week } & 105 & 1.0102(.06731)^{*} & .8345\end{array}$

$\begin{array}{cc}\text { Holding Period } & \text { N } \\ \text { 1-week } & 104 \\ \text { 2-week } & 104 \\ \text { 4-week } & 105 \\ \text { 13-week } & 105 \\ \text { (d) Subperiod I' (Oct 6,1982 - Feb 27,1985) }\end{array}$

$\begin{array}{lc}\text { Holding Period } & \mathrm{N} \\ \text { 1-week } & 120 \\ \text { 2-week } & 120 \\ \text { 4-week } & 120 \\ \text { 13-week } & 120\end{array}$

$\hat{\beta}$ (Std. Error)

$.5629(.03811)^{* \#}$

$.6071(.03849) * \#$

$.6750(.05029) * \#$

$.9670(.03600)^{*}$
$\mathrm{R}^{2}$

.5067

.6232

.6296

.8752

(b) Subperiod I (Sep1,1982 - Oct 10,1984)
$\mathrm{N}$

$\hat{\beta}$ (Std. Error)

120

120

120

120
$\mathrm{R}^{2}$

.5189

.6710

.6906

.9078

(e) Subperiod II' (Mar 6,1985 - Nov 26,1986)

$\begin{array}{ll}\text { Holding Period } & \text { N } \\ \text { 1-week } & 88 \\ \text { 2-week } & 87 \\ \text { 4-week } & 87 \\ \text { 13-week } & 86\end{array}$

$\mathrm{N}$
88
87
87
86

$\hat{\beta}$ (Std. Error) 
Table 4: Synthetic Hedge Results - EuroDeutsche Mark Deposit

(a) Entire Period (Jun 9,1982 - Nov 26,1986)

$\begin{array}{lccc}\text { Holding Period } & \mathrm{N} & \hat{\beta} \text { (Std.Error) } & \mathrm{R}^{2} \\ \text { 1-week } & 217 & .1719(.03069)^{* \#} & .1422 \\ \text { 2-week } & 216 & .2636(.04050)^{* \#} & .1859 \\ \text { 4-week } & 216 & .2481(.03681)^{* \#} & .2181 \\ \text { 13-week } & 204 & .4873(.03638)^{* \#} & .5629\end{array}$

(b) Subperiod I (Jun 9,1982 - Aug 29,1984)

$\begin{array}{lccc}\text { Holding Period } & \mathrm{N} & \hat{\beta} \text { (Std. Error) } & \mathrm{R}^{2} \\ \text { 1-week } & 105 & .1339(.04314)^{* \#} & .0973 \\ \text { 2-week } & 105 & .2307(.05928)^{* \#} & .1467 \\ \text { 4-week } & 105 & .2073(.05023)^{* \#} & .1720 \\ \text { 13-week } & 95 & .4286(.05438)^{* \#} & .4833\end{array}$

(c) Subperiod II (Sep 5,1984 - Nov 26,1986)

$\begin{array}{lccc}\text { Holding Period } & \mathrm{N} & \hat{\beta} \text { (Std. Error) } & \mathrm{R}^{2} \\ \text { 1-week } & 112 & .3810(.04263)^{* \#} & .4307 \\ \text { 2-week } & 111 & .3715(.05072)^{* \#} & .3428 \\ \text { 4-week } & 111 & .4377(.05930)^{* \#} & .4405 \\ \text { 13-week } & 107 & .7098(.04348)^{* \#} & .8061\end{array}$

(d) Subperiod I' (Oct 6,1982 - Feb 27,1985)

$\begin{array}{lccc}\text { Holding Period } & \mathrm{N} & \hat{\beta} \text { (Std. Error) } & \mathrm{R}^{2} \\ \text { 1-week } & 112 & .5847(.13644)^{* \#} & .1500 \\ \text { 2-week } & 111 & .7368(.10819)^{* \#} & .3189 \\ \text { 4-week } & 112 & .9652(.15628)^{*} & .3255 \\ \text { 13-week } & 107 & 1.1297(.11428)^{*} & .5430\end{array}$

(e) Subperiod II' (Mar 6,1985 - Nov 26,1986)

Holding Period N

1-week

2-week

4-week

13-week
88

88

87

84 $\hat{\beta}$ (Std. Error)

$1.0265(.14477)^{*}$

$.8736(.12432)^{*}$

$1.1297(.12792)^{*}$

$1.2279(.13564)^{*}$
$\mathrm{R}^{2}$

.3786

.3680

.5430

.5587

* Significantly different from zero at $5 \%$ level.

\# Significantly different from one at 5\% level. 
Table 5: Synthetic Hedge Results - EuroSwiss Franc Deposit

(a) Entire Period (Jun 9,1982 - Nov 26,1986)

$\begin{array}{lc}\text { Holding Period } & \text { N } \\ \text { 1-week } & 223 \\ \text { 2-week } & 22 \\ \text { 4-week } & 22\end{array}$

$\mathrm{N}$
223
222
222
213

$\hat{\beta}$ (Std. Error)

$\mathrm{R}^{2}$

13-week

213

$.2194(.04540)^{* \#}$

.1029

.0838

.1058

.3471

(b) Subperiod I (Jun 9,1982 - Aug 29,1984)

$\begin{array}{lccc}\text { Holding Period } & \mathrm{N} & \hat{\beta} \text { (Std. Error) } & \mathrm{R}^{2} \\ \text { 1-week } & 111 & .1994(.06052)^{* \#} & .0968 \\ \text { 2-week } & 111 & .1568(.05807)^{* \#} & .0680 \\ \text { 4-week } & 111 & .2040(.07800)^{* \#} & .0838 \\ \text { 13-week } & 105 & .6481(.14770)^{* \#} & .2500\end{array}$

(c) Subperiod II (Sep 5,1984 - Nov 26,1986)

$\begin{array}{lcccc}\text { Holding Period } & \mathrm{N} & \hat{\beta} \text { (Std. Error) } & \mathrm{R}^{2} \\ \text { 1-week } & 112 & .3433(.08159)^{* \#} & .1489 \\ \text { 2-week } & 111 & .4352(.08227)^{* \#} & .2178 \\ \text { 4-week } & 111 & .4378(.08310)^{* \#} & .2958 \\ \text { 13-week } & 108 & .5636(.08172)^{* \#} & .4501\end{array}$

(d) Subperiod I' (Oct 6,1982 - Feb 27,1985)

$\begin{array}{lccc}\text { Holding Period } & \mathrm{N} & \hat{\beta} \text { (Std. Error) } & \mathrm{R}^{2} \\ \text { 1-week } & 118 & .4586(.09491)^{* \#} & .1684 \\ \text { 2-week } & 118 & .4677(.09240)^{* \#} & .2056 \\ \text { 4-week } & 118 & .4323(.11927)^{* \#} & .1587 \\ \text { 13-week } & 112 & .4541(.11601)^{* \#} & .3026\end{array}$

(e) Subperiod II' (Mar 6,1985 - Nov 26,1986)

$\begin{array}{llcc}\text { Holding Period } & \mathrm{N} & \hat{\beta} \text { (Std. Error) } & \mathrm{R}^{2} \\ \text { 1-week } & 88 & .3234(.11102)^{* \#} & .1000 \\ \text { 2-week } & 87 & .4388(.09851)^{* \#} & .1970 \\ \text { 4-week } & 87 & .6042(.12966)^{* \#} & .2576 \\ \text { 13-week } & 84 & .8657(.09923)^{*} & .5343\end{array}$

* Significantly different from zero at $5 \%$ level.

\# Significantly different from one at $5 \%$ level 
Table 6: Synthetic Hedge Results - EuroYen Deposit

(a) Entire Period (Sep 1,1982 - Nov 26,1986)

$\begin{array}{lccc}\text { Holding Period } & \mathrm{N} & \hat{\beta} \text { (Std. Error) } & \mathrm{R}^{2} \\ \text { 1-week } & 211 & .1446(.03884)^{* \#} & .0648 \\ \text { 2-week } & 210 & .1751(.04270)^{* \#} & .0885 \\ \text { 4-week } & 210 & .2790(.05297)^{* \#} & .1823 \\ \text { 13-week } & 195 & .4595(.05631)^{* \#} & .3794\end{array}$

(b) Subperiod I (Sep 1,1982 - Oct 10,1984)

$\begin{array}{ll}\text { Holding Period } & N \\ \text { 1-week } & 105 \\ \text { 2-week } & 105 \\ \text { 4-week } & 105 \\ \text { 13-week } & 91\end{array}$

$\hat{\beta}$ (Std. Error)

$.0360(.04361) \#$

$.0596(.04616) \#$

$.1111(.05107)^{* \#}$

$.1688(.05319)^{* \#}$
$\mathrm{R}^{2}$

.0069

.0184

.0673

.1424

(c) Subperiod II (Oct 17,1984 - Nov 26,1986)

$\begin{array}{lc}\text { Holding Period } & \mathrm{N} \\ \text { 1-week } & 106 \\ \text { 2-week } & 105 \\ \text { 4-week } & 105 \\ \text { 13-week } & 104\end{array}$

$\hat{\beta}$ (Std. Error) $\quad R^{2}$

.1826

.2707

.5042

.6081

(d) Subperiod I' (Oct 6,1982 - Feb 27,1985)

$\begin{array}{ll}\text { Holding Period } & \mathrm{N} \\ \text { 1-week } & 118 \\ \text { 2-week } & 118 \\ \text { 4-week } & 118 \\ \text { 13-week } & 104\end{array}$

$\mathrm{N}$
118
118
118
104

$\hat{\beta}$ (Std. Error)

$\mathrm{R}^{2}$

.0069

.0187

.0895

.1308

(e) Subperiod II' (Mar 6,1985 - Nov 26,1986)

Holding Period N

$\hat{\beta}$ (T-Stat)

$\mathrm{R}^{2}$

1-week

88

2-week

87

4-week

87

13-week

85

$.6519(.11413)^{* \#}$

.2844

.3516

.5492

.6850

* Significantly different from zero at $5 \%$ level.

\# Significantly different from one at $5 \%$ level. 
Table 7: Covariance and Variance Measures for Daily Changes in Cash and Synthetic Futures Rates

(a) EuroSterling (Jan 1982 - Dec 1986)

$\begin{array}{lcccc}\text { Year } & \operatorname{Cov}\left(\Delta f_{t}, \Delta c_{t}\right) & \operatorname{Corr} \text { Coeff } & \operatorname{Var}\left(\Delta c_{t}\right) & \operatorname{Var}\left(\Delta f_{t}\right) \\ \text { Whole Sample } & .0120 & .2760 & .0250 & .0750 \\ 1982 & .0075 & .1960 & .0180 & .0810 \\ 1983 & .0027 & .0750 & .0100 & .1250 \\ 1984 & .0120 & .3320 & .0280 & .0470 \\ 1985 & .0280 & .4390 & .0490 & .0850 \\ 1986 & .0079 & .3210 & .0170 & .0350\end{array}$

(b) EuroCanadian Dollar (Jun 1982 - Dec 1986)

$\begin{array}{lcccc}\text { Year } & \operatorname{Cov}\left(\Delta f_{t}, \Delta c_{t}\right) & \text { Corr Coeff } & \operatorname{Var}\left(\Delta c_{t}\right) & \operatorname{Var}\left(\Delta f_{t}\right) \\ \text { Whole Sample } & .0049 & .1510 & .0300 & .0360 \\ 1982 & .0160 & .1850 & .0660 & .1080 \\ 1983 & .0002 & .0100 & .0150 & .0210 \\ 1984 & .0023 & .0720 & .0480 & .0210 \\ 1985 & .0034 & .1690 & .0130 & .0310 \\ 1986 & .0061 & .2850 & .0200 & .0230\end{array}$

(c) EuroDeutsche Mark (Jan 1982 - Dec 1986)

$\begin{array}{lcccc}\text { Year } & \operatorname{Cov}\left(\Delta f_{\mathfrak{t}}, \Delta c_{\mathfrak{t}}\right) & \operatorname{Corr~Coeff} & \operatorname{Var}\left(\Delta c_{\mathfrak{t}}\right) & \operatorname{Var}\left(\Delta f_{\mathfrak{t}}\right) \\ \text { Whole Sample } & .0011 & .0620 & .0058 & .0550 \\ 1982 & .0043 & .1150 & .0094 & .1520 \\ 1983 & -.0007 & -.0290 & .0083 & .0700 \\ 1984 & -.0003 & -.0310 & .0053 & .0240 \\ 1985 & .0013 & .1660 & .0035 & .0180 \\ 1986 & .0004 & .0940 & .0021 & .0078\end{array}$


Table 7 (continued)

(d) EuroSwiss Franc (Jan 1982 - Dec 1986)

Year $\operatorname{Cov}\left(\Delta f_{t}, \Delta c_{t}\right) \quad$ Cort Coeff $\operatorname{Var}\left(\Delta c_{t}\right)$

$\operatorname{Var}\left(\Delta f_{t}\right)$

Whole Sample

.0029

.0830

.0210

.0600

1982

.0094

.1180

.0440

.1430

1983

.0016

.0490

.0250

.0450

1984

.0020

.0910

.0120

.0390

1985

.0004

.0170

.0100

.0470

1986

.0002

.0170

.0110

.0200

(e) EuroYen (Jun 1982 - Dec 1986)

Year

$\operatorname{Cov}\left(\Delta f_{t}, \Delta c_{t}\right) \quad$ Corr Coeff

$\operatorname{Var}\left(\Delta c_{t}\right)$

$\operatorname{Var}\left(\Delta f_{t}\right)$

Whole Sample

.0014

.0790

.0060

.0510

1982

.0048

.1280

.0085

.1660

1983

$-.0011$

$-.0650$

.0051

.0580

1984

.0009

.0750

.0047

.0330

1985

.0023

.1480

.0077

.0310

1986

.0013

.1980

.0049

.0091 
Table 8 : Tests of the Stability of Intercept and Slope Coefficients in Synthetic Hedges

(a) EuroSterling Deposit

$\begin{array}{lcccccc}\text { Holding Period } & \hat{\alpha}_{0} & \hat{\beta}_{1} & \hat{\beta}_{2} & \hat{\beta}_{3} & \text { Wald Stat } & \mathrm{R}^{2} \\ \text { 1-week } & -.0182 & .4023 & .0226 & .2623 & 6.089^{\#} & .3225 \\ & (.01892) & (.07519)^{*} & (.02727) & (.10985)^{*} & & \\ \text { 2-week } & -.0427 & .6069 & .0777 & .1805 & 4.464^{\#} & .5165 \\ & (.04569) & (.07042)^{*} & (.06467) & (.10072) & & \\ \text { 4-week } & -.0955 & .7358 & .1761 & .1488 & 4.005^{\#} & .5653 \\ & (.07175) & (.08579)^{*} & (.10280) & (.12355) & & \\ \text { 13-week } & .2096 & 1.0196 & -.1297 & -.1221 & 2.990^{\#} & .8432 \\ & (.07831)^{*} & (.06045)^{*} & (.11727) & (.08418) & & \end{array}$

(b) EuroCanadian Dollar Deposit

$\begin{array}{lcccccc}\text { Holding Period } & \alpha_{0} & \hat{\beta}_{1} & \hat{\beta}_{2} & \hat{\beta}_{3} & \text { Wald Stat } & \mathrm{R}^{2} \\ \text { 1-week } & -.0174 & .5831 & -.0325 & -.0358 & 2.543^{\#} & .5109 \\ & (.01613) & (.05384)^{*} & (.02308) & (.07640) & & \\ \text { 2-week } & -.0289 & .6441 & .0511 & -.0669 & 2.341^{\#} & .6302 \\ & (.03325) & (.05437)^{*} & (.04707) & (.07623) & & \\ \text { 4-week } & -.0422 & .7607 & .0846 & -.1558 & 3.943^{\#} & .6466 \\ & (.05607) & (.06927)^{*} & (.08052) & (.09801) & & \\ \text { 13-week } & -.2034 & 1.0102 & -.0031 & -.0594 & .676 & .8761 \\ & (.08306) & (.06499)^{*} & (.11781) & (.07811) & & \end{array}$

Standard errors in parentheses

${ }^{*}$ Significantly different from zero at $5 \%$ level

\# Significant for rejection of joint equality of $\hat{\beta}_{2}$ and $\hat{\beta}_{3}$ to zero 
Table 8(Continued)

(c) EuroDeutsche Mark Deposit

Holding Period $\alpha_{0}$

$$
\hat{\beta}_{1}
$$

$\hat{\beta}_{2}$

$\hat{\beta}_{3} \quad$ Wald Stat

$\mathrm{R}^{2}$

1-week

.0019

.3810

$-.0318$

$-.2471$

$10.422^{\#}$

.1836 $(.01367)(.07631)^{*}(.01968)(.08301)^{*}$

2-week

.0046

.3715

$-.0464$

$-.1409$

$3.105^{\#}$

.2006 $(.02746)(.08433)^{*}(.03942)(.09589)^{*}$

4-week

$$
.0104
$$

.4377

$-.0930$

$-.2304$ $(.03996)(.09980)^{*}(.05694)(.10694)^{*}$

13-week

$$
\begin{array}{cccc}
-.1990 & .7098 & -.0743 & -.2813 \\
(.05946)^{*} & (.08333)^{*} & (.08849) & (.09247)^{*}
\end{array}
$$

$6.073^{\#} \quad .2534$

(d) EuroSwiss Franc Deposit

$\begin{array}{lcccccc}\text { Holding Period } & \alpha_{0} & \hat{\beta}_{1} & \hat{\beta}_{2} & \hat{\beta}_{3} & \text { Wald Stat } & \mathrm{R}^{2} \\ \text { 1-week } & -.0016 & .3433 & .0256 & -.1439 & 2.177^{\#} & .1111 \\ & (.02275) & (.11381)^{*} & (.03247) & (.12415) & & \\ \text { 2-week } & -.0066 & .4352 & .0409 & -.2784 & 4.846^{\#} & .1075 \\ & (.04510) & (.12699)^{*} & (.06386) & (.13621)^{*} & & \\ \text { 4-week } & -.0164 & .4378 & .0959 & -.2338 & 3.707^{\#} & .1331 \\ & (.06718) & (.14328)^{*} & (.09548) & (.15616) & & \\ \text { 13-week } & -.0176 & .5636 & -.2300 & .0845 & 2.755^{\#} & .3669 \\ & (.11812) & (.14041)^{*} & (.18631) & (.18101) & & \end{array}$

(e) EuroYen Deposit

$\begin{array}{lcccccc}\text { Holding Period } & \alpha_{0} & \hat{\beta}_{1} & \hat{\beta}_{2} & \hat{\beta}_{3} & \text { Wald Stat } & \mathrm{R}^{2} \\ \text { 1-week } & -.0075 & .3777 & .0014 & -.3417 & 17.990^{\#} & .1437 \\ & (.01244) & (.06715)^{*} & (.01776) & (.08095)^{*} & & \\ \text { 2-week } & -.0140 & .4342 & .0032 & -.3746 & 18.107^{\#} & .1757 \\ & (.02585) & (.07384)^{*} & (.03681) & (.08842)^{*} & & \\ \text { 4-week } & -.0493 & .7429 & .0356 & -.6318 & 40.470^{\#} & .3741 \\ & (.03623) & (.08604)^{*} & (.05195) & (.10097)^{*} & & \\ \text { 13-week } & -.0274 & .7632 & -.0033 & -.5944 & 41.460^{\#} & .5432 \\ & (.05187) & (.06959)^{*} & (.08345) & (.09722)^{*} & & \end{array}$


Table 9: Comparison of Synthetic Eurosterling Futures with LIFFE Domestic Sterling Futures

(1-week holding period)

\begin{tabular}{ccc} 
& \multicolumn{2}{c}{ Cash Market } \\
& Domestic Sterling & Eurosterling \\
LIFFE & $\mathrm{R}^{2}=.4511$ & $\mathrm{R}^{2}=.3736$ \\
& $\hat{\beta}=.7131$ & $\hat{\beta}=.7992$
\end{tabular}

Futures

Contract
Synthetic
$\mathrm{R}^{2}=.3274$
$\mathrm{R}^{2}=.2299$
Eurosterling
$\hat{\beta}=.4838$
$\hat{\beta}=.4634$

For 1-week hedges, entire period March 1983 - November 1986 (N=186)

Cash Market

Domestic Sterling Eurosterling

$\begin{array}{lll}\text { LIFFE } & \mathrm{R}^{2}=.4677 & \mathrm{R}^{2}=.3471 \\ & \hat{\beta}=.7922 & \hat{\beta}=.5132\end{array}$

Futures

Contract

Synthetic

$\mathrm{R}^{2}=.3471$

$\mathrm{R}^{2}=.1848$

Eurosterling

$\hat{\beta}=.5132$

$\hat{\beta}=.4634$

For 1-week hedges, subperiod I : March 1983 - January $1985(\mathrm{~N}=91)$

Cash Market

Domestic Sterling Eurosterling

LIFFE

$$
\begin{array}{ll}
\mathrm{R}^{2}=.4492 & \mathrm{R}^{2}=.4732 \\
\hat{\beta}=.6812 & \hat{\beta}=.7212
\end{array}
$$

Futures

Contract

Synthetic

Eurosterling

$\mathrm{R}^{2}=.3133$

$\mathrm{R}^{2}=.2720$

$\hat{\beta}=.4717$

$\hat{\beta}=.4534$

For 1-week hedges, subperiod II : Jan 1985 - November 1986 (N=95) 
Table 10: Comparison of Synthetic Eurosterling Futures with LIFFE Domestic Sterling Futures

(2-week holding period)

\begin{tabular}{ccc} 
& \multicolumn{2}{c}{ Cash Market } \\
& Domestic Sterling & Eurosterling \\
LIFFE & $\mathrm{R}^{2}=.5339$ & $\mathrm{R}^{2}=.5246$ \\
& $\hat{\beta}=.7976$ & $\hat{\beta}=.8466$
\end{tabular}

Futures

Contract

Synthetic

$\mathrm{R}^{2}=.4530$

$\mathrm{R}^{2}=.4842$

Eurosterling

$\hat{\beta}=.6057$

$\hat{\beta}=.6812$

For 2-week hedges, entire period March 1983 - November 1986 ( $\mathrm{N}=185)$

\section{Cash Market}

Domestic Sterling Eurosterling

LIFFE

$$
\begin{array}{cc}
\mathrm{R}^{2}=.5787 & \mathrm{R}^{2}=.5854 \\
\hat{\beta}=1.0103 & \hat{\beta}=1.1507
\end{array}
$$

Futures

Contract

Synthetic

Eurosterling

$$
\begin{aligned}
& \mathrm{R}^{2}=.4380 \\
& \hat{\beta}=.6579
\end{aligned}
$$$$
\mathrm{R}^{2}=.5424
$$$$
\hat{\beta}=.8701
$$

For 2-week hedges, subperiod I : March 1983 - January 1985 (N=92)

\section{Cash Market}

\section{Domestic Sterling Eurosterling}

LIFFE

$$
\begin{aligned}
& \mathrm{R}^{2}=.5487 \\
& \hat{\beta}=.7025
\end{aligned}
$$$$
\mathrm{R}^{2}=.5621
$$$$
\hat{\beta}=.7068
$$

Futures

Contract

Synthetic

Eurosterling
$\mathrm{R}^{2}=.4764$

$\hat{\beta}=.5876$
$\mathrm{R}^{2}=.4772$

$\hat{\beta}=.5846$

For 2-week hedges, subperiod II : Jan 1985 - November 1986 (N=93) 
Table 11: Comparison of Synthetic Eurosterling Futures with LIFFE Domestic Sterling Futures

(4-week holding period)

Cash Market

Domestic Sterling Eurosterling

LIFFE

$$
\begin{array}{ll}
\mathrm{R}^{2}=.6147 & \mathrm{R}^{2}=.5895 \\
\hat{\beta}=.8921 & \hat{\beta}=.9205
\end{array}
$$

Futures

Contract

Synthetic

Eurosterling
$\mathrm{R}^{2}=.5184$

$\mathrm{R}^{2}=.5068$

$\hat{\beta}=.7565$

$\hat{\beta}=.7893$

For 4-week hedges, entire period March 1983 - November $1986(\mathrm{~N}=185)$

Cash Market

Domestic Sterling Eurosterling

LIFFE

$$
\begin{array}{cc}
\mathrm{R}^{2}=.6401 & \mathrm{R}^{2}=.5961 \\
\hat{\beta}=1.0816 & \hat{\beta}=1.1982
\end{array}
$$

Futures

Contract

Synthetic

Eurosterling
$\mathrm{R}^{2}=.5380$

$\mathrm{R}^{2}=.5035$

$\hat{\beta}=.8258$

$\hat{\beta}=.9348$

For 4-week hedges, subperiod I : March 1983 - January 1985 (N=92)

Cash Market

Domestic Sterling Eurosterling

LIFFE

$$
\begin{array}{ll}
\mathrm{R}^{2}=.6356 & \mathrm{R}^{2}=.6447 \\
\hat{\beta}=.8509 & \hat{\beta}=.8447
\end{array}
$$

Futures

Contract

Synthetic

Eurosterling
$\mathrm{R}^{2}=.5171$

$\mathrm{R}^{2}=.5311$

$\hat{\beta}=.7488$

$\hat{\beta}=.7480$

For 4-week hedges, subperiod II : Jan 1985 - November 1986 (N=93) 
Table 12: Comparison of Synthetic Eurosterling Futures with LIFFE Domestic Sterling Futures

(13-week holding period)

Cash Market

Domestic Sterling Eurosterling

LIFFE

$$
\begin{array}{cc}
R^{2}=.8383 & R^{2}=.8317 \\
\hat{\beta}=1.0036 & \hat{\beta}=1.0155
\end{array}
$$

Futures

Contract

Synthetic

Eurosterling
$\mathrm{R}^{2}=.7975$

$\hat{\beta}=1.0249$

$\mathrm{R}^{2}=.8060$

$\hat{\beta}=1.0484$

For 13-week hedges, entire period March 1983 - November $1986(\mathrm{~N}=185)$

Cash Market

Domestic Sterling Eurosterling

LIFFE

$$
\begin{array}{ll}
\mathrm{R}^{2}=.6984 & \mathrm{R}^{2}=.6188 \\
\hat{\beta}=1.0151 & \hat{\beta}=.9355
\end{array}
$$

Futures

Contract

Synthetic

Eurosterling
$\mathrm{R}^{2}=.6194$

$\hat{\beta}=.9415$
$\mathrm{R}^{2}=.6132$

$\hat{\beta}=.9389$

For 13-week hedges, subperiod I : March 1983 - January 1985 ( $N=92)$

Cash Market

Domestic Sterling Eurosterling

LIFFE

$$
\begin{array}{ll}
\mathrm{R}^{2}=.8589 & \mathrm{R}^{2}=.8709 \\
\hat{\beta}=.9875 & \hat{\beta}=1.0112
\end{array}
$$

Futures

Contract

\author{
Synthetic \\ Eurosterling
}

$\mathrm{R}^{2}=.8259$

$\mathrm{R}^{2}=.8395$

$\hat{\beta}=1.0159$

$\hat{\beta}=1.0419$

For 13-week hedges, subperiod II : Jan 1985 - November 1986 ( $N=93$ ) 
Table 13: Comparison of Synthetic Eurosterling Futures with LIFFE Domestic Sterling Futures - F Statistics

(For entire period March 1983 - November 1986)

\section{Cash Market}

Domestic Sterling

1-week

2-week

4-week

13-week
1.2254

1.1736

$1.4299^{*}$

1.2523
Eurosterling

1.2294

1.0849

1.0241

1.1527

* Significant for rejection of the null hypothesis at $5 \%$ level. 
Table 14: Comparison of Transaction Costs Between Actual LIFFE Sterling Futures Contract and Synthetic Euro-Sterling Futures Contract

Synthetic Contract for 500,000 Pounds

1 CME Euro-dollar futures

$\$ 11.00$

(contract size is $\$ 1,000,000$ )

$8 \mathrm{CME} \$ /$ pound near-term currency futures

72.00

$8 \mathrm{CME} \$$ /pound far-term currency futures

72.00

(contract size is 62,500 pounds)

Total $\quad 155.00$

Actual LIFFE Sterling Futures Contract

1 LIFFE contract (size is 500,000 pounds)

18.00

Difference $\$ 137.00$

Note: At $\$ 25$ per tick, $\$ 137$ equals 5.48 ticks. If a LIFFE sterling contract were priced at $87.50(12.50 \%)$, a synthetic contract would have to be priced at 87.44 (on the buy side) or 87.56 (on the sell side) to make the synthetic contract competitive in terms of price.

Calculation assumes exchange rate of $\$ 2.00$ /pound

Source: Transaction costs supplied by large New York futures trading firm. 


\section{References}

1. Bank for International Settlements. Recent Innovations in International Banking, (Basle: BIS), 1986.

2. Black, D.G., "Success and Failure of Futures Contracts : Theory and Empirical Evidence," Salomon Brothers Center for the Study of Financial Institutions, Monograph Series in Finance and Economics, Monograph 1986-1.

3. Cornell, B., and Reinganum, M., "Forward and Furures Price: Evidence from the Foreign Exchange Markets", Journal of Finance, 36, No. 5, December 1981, pp.1035-1045.

4. Cox, J.L., Ingersoll, J.E. and Ross, S.A., "The Relation Between Forward Prices and Futures Prices," Journal of Financial Economics, 1981, Vol.9, pp.321-346.

5. Cumby, R.E., Huizinga, J. and Obstfeld, M., "Two-Step Two-Stage Least Squares Estimation in Models with Rational Expectations," Journal of Econometrics, Vol. 21, 1983, pp.333-355.

6. Figlewski, S., Hedging with Financial Futures for Institutional Investors: From Theory to Practice. Ballinger Publishing Co., Cambridge, Massachusetts, 1986.

7. Franckle, C.T. and Senchack, A.J.Jr., "Economic Considerations in the Use of Interest Rate Futures," The Journal of Futures Markets, 1982, Vol.2, No.1, pp.107-116.

8. Frenkel, Jacob A. and Levich, Richard M. "Spot and Forward Contracts," in J. Eatwell, M. Milgate, and P.Newman (eds.), The New Palgrave: A Dictionary of Economic Thought and Doctrine. (London: Macmillan), Vol. 4, pp.442-4, 1988.

9. Hansen, L. and Hodrick, R., "Risk Averse Speculation in the Forward Foreign Exchange Market," in J.Frenkel (ed.) Exchange Rates and International Macroeconomics, (Chicago: University of Chicago Press), 1980.

10. Jarrow, R.A. and Oldfield, G.S., "Forward Contracts and Futures Contract," Joumal of Financial Economics, 1981, Vol.9, pp.373-382. 
11. Koh, Annie. A Study on the Effectiveness of Hedging Dollar and Non-Dollar Borrowing Costs with Eurodollar and Currency Futures Contracts, Unpublished Ph.D. dissertation, New York University, April 1988.

12. Levich, R.M., "The Efficiency of Markets for Foreign Exchange: A Review and Extension," in R.Kolb and G.Gay (eds.), Intemational Finance : Concepts and Issues, Richmond, VA; Robert F.Dame, Inc, 1982.

13. Levich, Richard M. "Financial Innovations in International Financial Markets," in M. Feldstein (ed.), The United States in the World Economy, (Chicago: University of Chicago Press), 1988.

14. Morgan Guaranty Trust Company. World Financial Markets, August 17,1988.

15. Overdahl, J.A. and Starleaf, D.R., "The Hedging Performance of the CD Futures Markets," The Journal of Futures Markets, 1986, Vol.6, No.1, pp.71-81.

16. Peck, A.E., "Hedging and Income Stability: Concepts, Implications and An Example," Joumal Paper 5858, 1975, Purdue University Agricultural Experiment Station.

17. Richard, S.F. and Sundaresan, M., "A Continuous Time Equilibrium Model of Commodity Prices in a Multigood Economy," Joumal of Financial Economics, 1981, Vol. 9, pp.347-371.

18. Rombach, Edward and Walsh, Carl . "Synthesising Non-Dollar Interest Rate Futures," Bisk, Vol.1, No.9, August-September 1988. 